\title{
Production of Spirulina platensis by adding sodium bicarbonate and urea into chicken manure medium
}

\author{
Hilal Kargin Yilmaz ${ }^{1 *}$ and Özlem Sezgin ${ }^{2}$ \\ ${ }^{1}$ Faculty of Fisheries, University of Mersin, Mersin, Turkey. \\ ${ }^{2}$ University of Mersin, Graduate School of Natural and Applied Sciences, Mersin, Turkey. \\ Received 2 February, 2014; Accepted 24 March, 2014
}

\begin{abstract}
In this study, dry chicken manure (DCM) was used as the source of nitrogen in the production of Spirulina platensis. Experiment was conducted in two different types of nutrition. In the type I nutrition, the highest average cell increase was recorded as 289.70 filaments $\mathrm{mL}^{-1}$ in value in the type I group (DCM+urea). In the type II nutrition, the highest average cell increase was recorded as 296.50 filament $\mathrm{mL}^{-1}$ in value in the type II group (DCM+urea+sodium bicarbonate). In the type I nutrition (DCM+Urea), the highest specific growth rate was detected as 0.21 division day $^{-1}$ on the sixth day and $\mathrm{k}$ value as being 0.30 division day ${ }^{-1}$. In the type II nutrition, the highest specific growth rate was recorded as 0.08 division day ${ }^{-1}$ in the group II ( $\left(\mathrm{DCM}+\mathrm{Urea}+\mathrm{NaHCO}_{3}\right)$ and $\mathrm{k}$ value as being 0.12 division day ${ }^{-1}$. In both types of nutrition, the protein rates of the type I group (DCM+urea) and the group III (DCM+sodium bicarbonate) are found to be higher than that in the other groups. The lipid levels in both types of nutrition, in DCM (Control) and in the type I group (DCM+Urea) were found to be higher than the other groups.
\end{abstract}

Key words: Spirulina platensis, dry chicken manure, sodium bicarbonate, urea.

\section{INTRODUCTION}

Spirulina platensis (Geitler, 1932) is a species of cyanobacteria with a commercial value. It is a species of microalgae with thread-like structure constituting intensive populations in tropic and sub-tropic waters characterized with high carbonate, bicarbonate and the highest $\mathrm{pH}$ value (Binaghi et al., 2003). S. platensis production has been launched in Turkey and has find a place in the region of nutraceuticals and pharmaceuticals fields' market (Blunden et al., 1992). Spirulina sp. is being used in combined feed of poultry, being an active biological additive due to high protein concentration, essential amino acids, vitamins, $\beta$-carotene, minerals, polysaccharides and essential fatty acids (Babadzhanov et al., 2004; Venkataraman et al., 1994). Spirulina is also stated to be a natural colorant. Hence, it is stated that it is being used in chicken eggs and fish feed; in aquaculture as natural colorant (Challem, 1981). It is also revealed that the cost can vary for the various nutrition compositions and nutrient environment for the biomass productivity of Spirulina sp. (Kendirli, 2010).

Microalgae are in the need of basic elements such as carbon $(\mathrm{C})$, nitrogen $(\mathrm{N})$ and phosphorus $(\mathrm{P})$ in order to conduct the organic substance synthesis (Davis, 1977). In cultures, the most important inorganic $\mathrm{N}$ sources that

${ }^{*}$ Corresponding author. E-mail: karginyilmaz@hotmail.com.

Author(s) agree that this article remain permanently open access under the terms of the Creative Commons Attribution License 4.0 International License 
Table 1. Nutrient media used in the experiment.

\begin{tabular}{|c|c|}
\hline Nutrition type I groups of nutrient media & Nutrition type II groups of nutrient media \\
\hline DCM (Control): tap water was added every $24 \mathrm{~h}$ & DCM (Control): tap water was added every $24 \mathrm{~h}$ \\
\hline (DCM+Urea): urea $(2.0 \mathrm{mg} / \mathrm{L})$ was added every $24 \mathrm{~h}$ & (DCM+Urea): urea $(1.0 \mathrm{mg} / \mathrm{L})$ was added every $24 \mathrm{~h}$ \\
\hline $\begin{array}{l}\left(\mathrm{DCM}+\mathrm{Urea}+\mathrm{NaHCO}_{3}\right): \text { urea }(2.0 \mathrm{mg} / \mathrm{L}) \text { and sodium bicarbonate } \\
(40 \mathrm{mg} / \mathrm{L}) \text { were added every } 24 \mathrm{~h}\end{array}$ & $\begin{array}{l}\left(\mathrm{DCM}+\mathrm{Urea}+\mathrm{NaHCO}_{3}\right): \text { urea }(1.0 \mathrm{mg} / \mathrm{L}) \text { and sodium } \\
\text { bicarbonate }(20 \mathrm{mg} / \mathrm{L}) \text { were added every } 24 \mathrm{~h}\end{array}$ \\
\hline $\begin{array}{l}\left(\mathrm{DCM}+\mathrm{NaHCO}_{3}\right) \text { : sodium bicarbonate }(40 \mathrm{mg} / \mathrm{L}) \text { was added } \\
\text { every } 24 \mathrm{~h}\end{array}$ & $\begin{array}{l}\text { (DCM+NaHCO3): sodium bicarbonate }(20 \mathrm{mg} / \mathrm{L}) \text { was added } \\
\text { every } 24 \mathrm{~h}\end{array}$ \\
\hline
\end{tabular}

are able to be used by the cells are as follows; $\mathrm{NO}_{3}$ nitrogen $\left(\mathrm{NO}_{3}-\mathrm{NN}\right), \mathrm{NH}_{4}$ nitrogen $\left(\mathrm{NH}_{4}-\mathrm{N}\right)$ and urea nitrogen $\left(\left(\mathrm{NH}_{2}\right)_{2} \mathrm{CO}-\mathrm{N}\right)$ (Gökpınar, 1991). S. platensis, as opposed to the other photosynthetic microorganisms is able to use ammonia in high $\mathrm{pH}$ values. The penetration of ammonia into cell for an average inner cell $\mathrm{pH}\left(\mathrm{pH}_{\mathrm{av}}\right)$ and the outer environment $\mathrm{pH}\left(\mathrm{pH}_{\mathrm{out}}\right)$ is depended on the difference (delta $\mathrm{pH}$ ) and limits the high $\mathrm{pH}$ average of inner cell. This high $\mathrm{pH}$ value is found to be pressured by inner thylakoid $\mathrm{pH}$ (Boussiba, 1989). Urea is converted to ammonia by hydrolysis in the alkaline culture media. This emerging ammonia in high concentration is able to create toxic impact for microalgae. However, addition of urea in discontinuous nutrition period enables the use of $\mathrm{KNO}_{3}$ as the source of nitrogen in culture medium. On the other hand, it is stated that working in the industrial scale might be simpler with constant urea addition (Danesi et al., 2004).

Another way of reasonable utilization of farm manure is to use it in the production of microalgae. Nitrogen source for S. platensis is known to be nitrate. Furthermore, the farmers managed to produce Spirulina sp. using the manure disposals of pig and chicken farms as the source of nitrogen (Ungsethaphand et al., 2007). By doing so, they cut back on purchasing expensive feed additive, at the same time utilizing from the waste water, they have provided as an economic contribution (Cheunbarn et al., 2010). Algae use solar energy whilst absorbing nutrients using the carbonized substances from the waste waters in order to produce biomass. Biomass which is obtained from the useful part of the waste water ingredient is able to be used in animal feed as being a valuable nutrient source (Ratana et al., 2009). Later, researches showed that dry chicken manure provides the necessary nutrient source for S. platensis culture (Ungsethaphand et al., 2007).

In Turkey, the research on organic manure usage for $S$. platensis production is not yet sufficient. The aim of this study is to achieve the low cost production of $S$. platensis by adding urea and sodium bicarbonate into dry chicken manure and to determine the protein and lipid levels of the yield.

\section{MATERIALS AND METHODS}

S. platensis was produced in the Plankton Laboratory of Mersin
University of Fisheries Faculty. As the culture environment Spirulina liquid medium was used by having been modified. $\mathrm{NaNO}_{3}$ was not used in the modified Spirulina medium (Schlosser, 1982). Part I: $180.6 \mathrm{~g} \mathrm{NaHCO}_{3} ; 80.6 \mathrm{~g} \mathrm{Na}_{2} \mathrm{CO}_{3} ; 10.0 \mathrm{~g} \mathrm{~K}_{2} \mathrm{HPO}_{4}$; Part II: $20.0 \mathrm{~g}$ $\mathrm{K}_{2} \mathrm{SO}_{4} ; 20.0 \mathrm{~g} \mathrm{NaCl} ; 4.0 \mathrm{~g} \mathrm{MgSO}_{4} .7 \mathrm{H}_{2} \mathrm{O} ; 2.0 \mathrm{~g} \mathrm{CaCl}_{2} .2 \mathrm{H}_{2} \mathrm{O} ; 20.0 \mathrm{~g}$ $\mathrm{FeSO}_{4} .7 \mathrm{H}_{2} \mathrm{O} ; 1.6 \mathrm{~g} \mathrm{EDTANa}_{2}$ and $100 \mathrm{~m}$, micro nutrient solution (0.001 $\mathrm{g} \mathrm{ZnSO}_{4} .7 \mathrm{H}_{2} \mathrm{O} ; 0.002 \mathrm{~g} \mathrm{MnSO}_{4} .7 \mathrm{H}_{2} \mathrm{O} ; 0.01 \mathrm{~g} \mathrm{H}_{3} \mathrm{BO}_{3} ; 0.001 \mathrm{~g}$ $\mathrm{Na}_{2} \mathrm{MoO}_{4} .2 \mathrm{H}_{2} \mathrm{O} ; 0.001 \mathrm{~g} \mathrm{Co}\left(\mathrm{NO}_{3}\right)_{2} .6 \mathrm{H}_{2} \mathrm{O} ; 0.00005 \mathrm{~g} \mathrm{CuSO}_{4} .5 \mathrm{H}_{2} \mathrm{O}$; $0.7 \mathrm{~g} \mathrm{FeSO}_{4} .7 \mathrm{H}_{2} \mathrm{O} ; 0.8 \mathrm{~g} \mathrm{EDTANa}$ ). Part I and II were prepared by being added into $10 \mathrm{~L}$ of pure water. To constitute a inoculation culture; firstly, the cells of Spirulina are filtered through a $30 \mu \mathrm{m}$ mesh net and to purify from sodium nitrate washed three times with $0.8 \% \mathrm{NaCl}$ solution and harvested. Stabilizing the initial $\mathrm{pH}$ value at 10 and the temperature at $34 \pm 1^{\circ} \mathrm{C}$, cells of Spirulina was inoculated into modified Spirulina medium. Initial culture was carried out by providing moderate aeration in $1 \mathrm{~L}$ flasks. $24 \mathrm{~h}$ of lighting was applied with daylight fluorescent lamps and when the culture reached to maximum intensity, the cell was inoculated into the prepared manure syrup.

In the experiment, $200 \mathrm{~g}$ of dry chicken manure which has been provided from a chicken farm was used for the culture medium. Dry chicken manure was powdered with a feed grinding machine and the powder sieved through $30 \mu \mathrm{m}$ mesh net. Then, it was waited in $10 \mathrm{~L}$ tap water filtered through $0.45 \mu \mathrm{m}$ membrane filter and aerated for seven days. Furthermore, sodium metabisulfide $\left(5 \mathrm{mg} \mathrm{L}^{-1}\right)$ was added into the medium in order to prevent the microbial contamination. In addition, the manure syrup was waited in $121^{\circ} \mathrm{C}$ in an autoclave for $15 \mathrm{~min}$ sterilizing. $24 \mathrm{~h}$ after the commencement of the experiment, $8.5 \mathrm{~g} \mathrm{~L}^{-1}$ of sodium bicarbonate was also added. The experiment was conducted in $10 \mathrm{~L}$ of glass tanks in discontinuous mode for 10 days. Each of them was aerated by a central aeration system.

The nutrient media and quantities used in the experiment are shown in Table 1. The addition of urea and sodium bicarbonate was conducted at the time of feeding. The experiments were conducted in two different types of nutrition on $4 \times 3$ experimental designs, in 8 groups each, three times repeatedly.

\section{Inoculation}

The Spirulina cells (500 filaments $\mathrm{mL}^{-1}$ density) purified from nitrate were inoculated into the water with manure. Culture tanks were prepared with $5.5 \mathrm{~L}$ water with manure and by the inoculation of 4.5 L Spirulina cells.

\section{Obtaining of the S. platensis yields}

S. platensis yields harvested from the type I and II nutrition were filtered through a $30 \mu \mathrm{m}$ mesh net. Yields were kept waiting in the laboratory environment for one day and then the drying process was applied at $50^{\circ} \mathrm{C}$ temperature for three days in the incubator. The dried yields were preserved in the refrigerator and a second 
drying process was applied at $65^{\circ} \mathrm{C}$ for 45 min before analyzing process.

The calculation of filament number and specific growth rate of S. platensis

Single drop method was used in the calculation of filament number (Semina, 1978). After each sample was counted at least 3 repeats, the filament number at $1 \mathrm{ml}$ was calculated. In the experiment, the specific growth rate of Spirulina was calculated according to the formula below (Guillard, 1973);

$$
\mu=\frac{\ln \mathrm{Nt}-\ln \mathrm{N} 0}{\mathrm{t} 1-\mathrm{t} 0}
$$

$\mu$ : Specific growth rate, Nt: Number of cells at the end of the experiment, $\mathrm{N}_{0}$ : Initial cell number, t: Time (day).

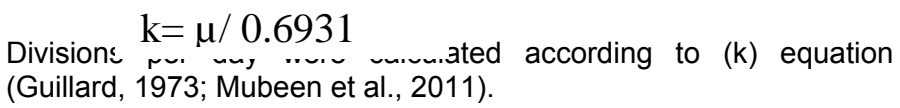

\section{Chemical analysis}

Kjeldahl method (AOAC, 1984) was applied in the protein analysis and Blig and Dyer (1959) method was applied in lipid analysis.

\section{Statistical analysis}

The statistical analysis were made using SPSS 16.0 software package and the comparisons were carried out with one-way ANOVA-Duncan method.

\section{RESULTS AND DISCUSSION}

In the type I nutrition, the increase of cells in the type I group of the sixth day are detected respectively as follows: 326.67 filament $\mathrm{ml}^{-1} ; 336.33$ filament $\mathrm{ml}^{-1} ; 357.67$ filament $\mathrm{ml}^{-1} ; 317.67$ filament $\mathrm{ml}^{-1} ; 260.33$ filament $\mathrm{ml}^{-1}$ and are found to be different statistically in comparison to other groups $(p<0.05)$. In the type I nutrition, average cell increase (289.70 filament $\left.\mathrm{ml}^{-1}\right)$ was found to be in the highest level (Figure 1). In the experiment; in the type I nutrition, the ideal cell increase was detected in the type I group in the urea added nutrient medium. Costa et al. (2004) reported that the highest cell increase is obtained from the type I group with the addition of urea in which no sodium bicarbonate is added. The result which the researchers reported matches the results we had obtained. In various studies that have been conducted, it is stated that in S. platensis cultures, as the source of nitrogen increases, the use of urea causes an increase of cell (Stanca and Popovici, 1996). The result that they had obtained matches the findings we obtained as the result of our studies. Xu et al. (2001) reported that nitrogen sources and concentrations are one of the important factors in effecting the growth and biochemical composition in algae cultures. In the chicken manure medium with rich nitrogen, $2.0 \mathrm{mg} \mathrm{L}^{-1}$ of urea urged the increase of cell of $S$. platensis and affected its growth and biochemical structure positively in our study. Vonshak et al. (1982) reported that only when sodium bicarbonate is added, the increase of cell was affected negatively. They reported that in dark cycle at high temperatures, due to the increase in respiratory activity, cells apply the consumption of carbohydrates for respiration and this resulted in a decrease of cell growth.

According to the results of this study, the increase of cell that was found in the group with the sodium bicarbonate added is consistent with the Vonshak et al. (1982) result which they had reported. In that sense, the decrease in the cell increase can be connected to high $\mathrm{CO}_{2}$ and high bicarbonate rates depended on the acceleration of photosynthesis and fast carbohydrate consumption. In the type II nutrition, the second day, the increase of cell in the type II group were defined respectively; 324.00 filament $\mathrm{ml}^{-1} ; 311.33$ filament $\mathrm{ml}^{-1}$; 320.33 filament $\mathrm{ml}^{-1} ; 318.67$ filament $\mathrm{ml}^{-1} ; 345.00$ filament $\mathrm{ml}^{-1} ; 325.00$ filament $\mathrm{ml}^{-1} ; 259.33$ filament $\mathrm{ml}^{-1} ; 233.00$ filament $\mathrm{ml}^{-1} ; 220.00$ filament $\mathrm{ml}^{-1}$. However, in the type II group nutrition, the average increase of cell $\left(296.50 \mathrm{ml}^{-1}\right.$ filament) was found to be the ideal $(p<0.05)$ (Figure 1$)$. In the type II nutrition, from the second day, the increase of cell in the type I group were defined respectively; 340.00 filament $\mathrm{ml}^{-1} ; 321.33$ filament $\mathrm{ml}^{-1} ; 329.00$ filament $\mathrm{ml}^{-1}$; 302.67 filament $\mathrm{ml}^{-1} ; 270.00$ filament $\mathrm{ml}^{-1} ; 231.33$ filament $\mathrm{ml}^{-1} ; 165.33$ filament $\mathrm{ml}^{-1}$. From sixth day, any considerable difference was not found between type II group with type I group and other groups( $p>0.05)$. But, significant differences were found between type II group with other groups after sixth day $(p<0.05)$. The highest increase of cell took place in the type II nutrition due to the rates of urea and sodium bicarbonate which was halved compared to the type I nutrition. However, as opposed to the increase of cell, decrease in the rates of protein was observed. The reason for this is the nitrogen source and levels being one of the most important factors affecting the growth and biochemical contents in algae cultures. The growth is affected by concentrations as well as by nourishing elements that are used in the nutrition environments (Xu et al., 2001). It is concluded that the decrease in the protein ratios is the result of sodium bicarbonate pressuring the nitrogen levels in the environment, slowing down the protein metabolism and augmenting carbohydrate metabolism.

In the type I nutrition, the specific growth rates in the second, fourth, sixth, seventh and eighth days were recorded as being respectively; 0.07 division day ${ }^{-1} ; 0.01$ division day ${ }^{-1} ; 0.21$ division day $^{-1} ; 0.03$ division $^{-1} y^{-1} ; 0.06$ division day ${ }^{-1}$. The most ideal specific growth rate in the type I group was found to be 0.21 division day ${ }^{-1}$ and $k$ value as being 0.30 division $^{-1 a y^{-1}}$. The specific growth rate in the type II group, in the second day was found to be 0.06 division day ${ }^{-1}$ and the $k$ value as 0.09 division 


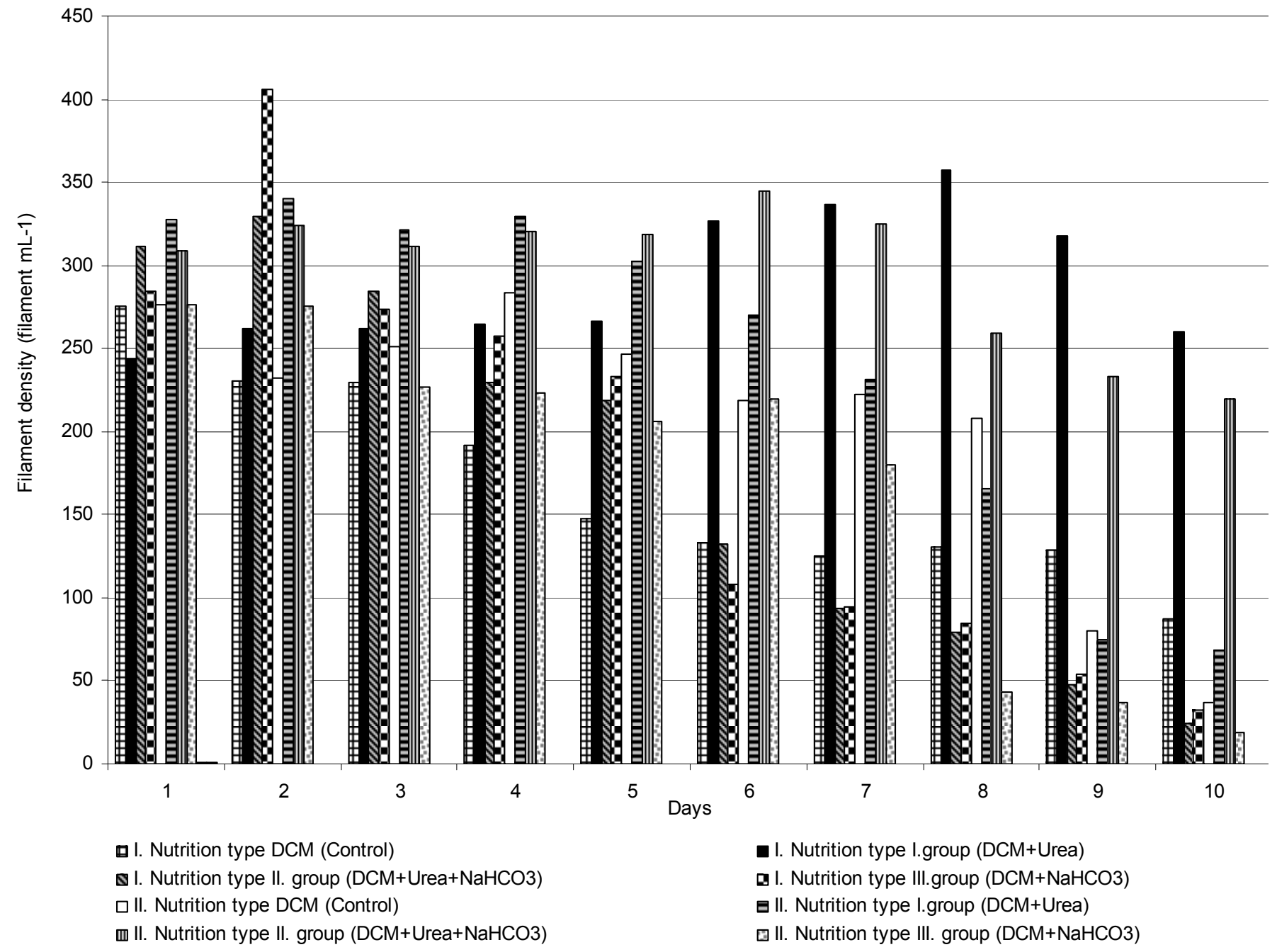

Figure 1. Daily increases in filament densities of S. platensis were cultivated in I and II type of nutrition with DCM.

day $^{-1}$. The specific growth rate in the type III group, in the second day was found to be 0.36 division $\mathrm{day}^{-1}$ and the $\mathrm{k}$ value as 0.52 division day ${ }^{-1}$. The specific growth rate in the control group, in the eighth day was found to be 0.04 division day $^{-1}$ and the $\mathrm{k}$ value as 0.06 division day $^{-1}$ (Figures 2 and 3 ). In the type II nutrition, the specific growth rates in the second, fourth and the fifth day were recorded respectively; 0.04 division day ${ }^{-1} ; 0.03$ division day $^{-1} ; 0.05$ division day ${ }^{-1}$. The specific growth rates in the second day were recorded to be 0.04 division $^{-1 a y}{ }^{-1}$ and the $\mathrm{k}$ value as being 0.06 division day $^{-1}$; in the fourth day was 0.03 division day- ${ }^{1}$ and the $\mathrm{k}$ value as being 0.04 division day ${ }^{-1}$; in the fifth day was 0.05 division day $^{-1}$ and the $\mathrm{k}$ value as 0.07 division $\mathrm{day}^{-1}$. The specific growth rates in the second, fourth and the sixth day were recorded respectively; 0.05 division day ${ }^{-1} ; 0.03$ division day $^{-1} ; 0.08$ division day ${ }^{-1}$.

The highest specific growth rate in the type II group was found to be 0.08 division day $^{-1}$ and the $\mathrm{k}$ value is recorded as 0.12 division day ${ }^{-1}$. The specific growth rate

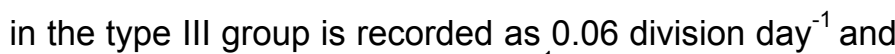
the $k$ value as 0.09 division day ${ }^{1}$. The specific growth rates in the control group in the third, fourth and the seventh day were recorded respectively; 0.08 division day $^{-1} ; 0.12$ division day ${ }^{-1} ; 0.02$ division day ${ }^{-1}$. The specific growth rate in the control group in the fourth day is recorded to be 0.12 division day ${ }^{-1}$ and the $\mathrm{k}$ value as 0.17 division day ${ }^{-1}$ (Figures 2 and 3). Vonshak et al. (1982) reported that in the group where low cell increase had taken place, high specific growth was observed. Similarly, in our study in the groups where low cell increase had taken place, a maximum specific growth rate ( $\mu$ max) was obtained. Vonshak et al. (1982) detected the $\mu$ max rates as 0.048 to 0.054 division day ${ }^{-1}$ and this is consistent with the specific growth rates $\left(0.04\right.$ to 0.08 division day $\left.^{-1}\right)$ as we had obtained in our study.

There was no statistical discrepancies observed in the two different nutrition media in terms of lipid levels $(p>0.05)$. Between I to II groups and III to IV groups of the type I nutrition media statistical discrepancies were found 


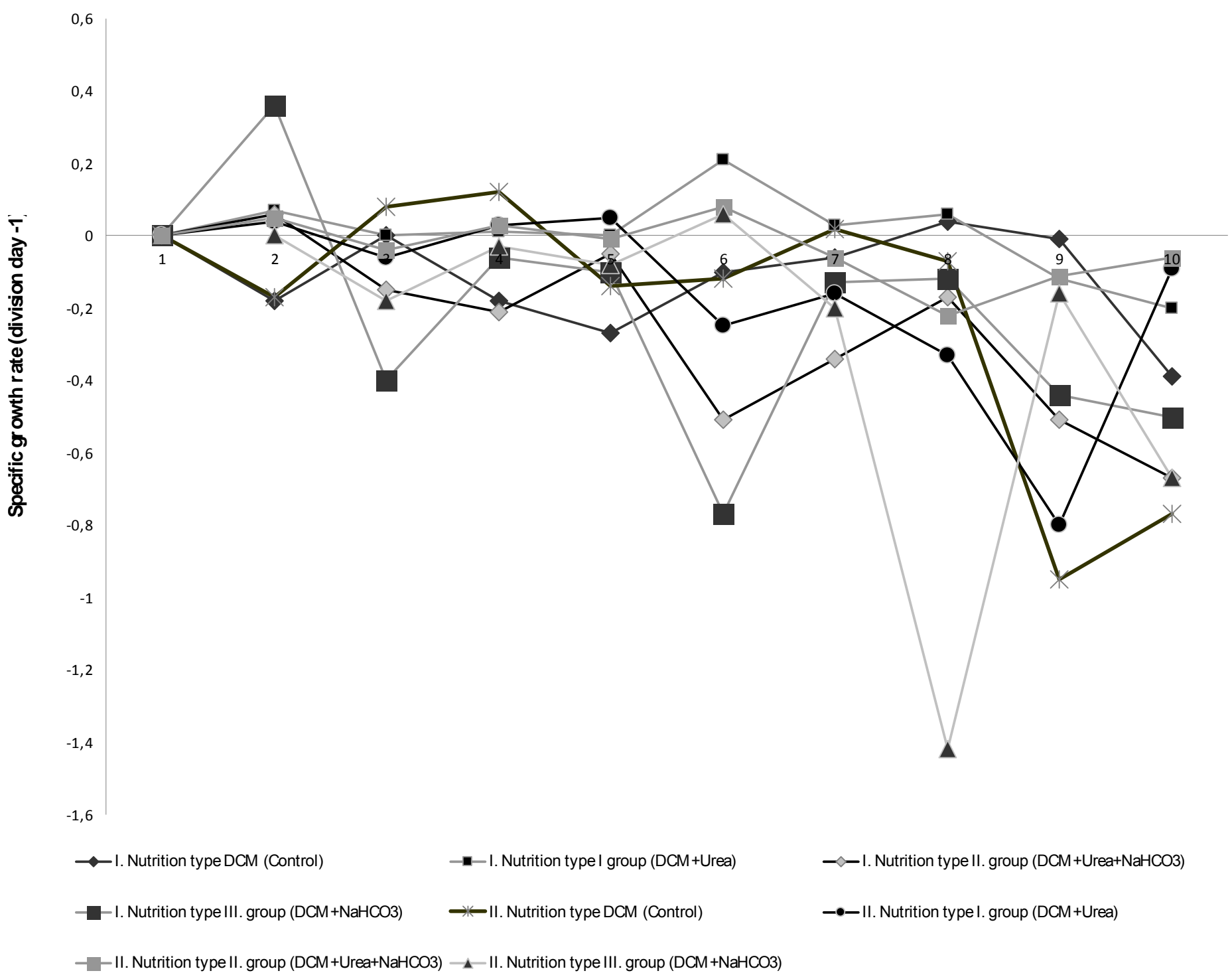

Figure 2. Daily increases in specific growth rates of S. platensis were cultivated in I and II type of nutrition with DCM.

$(p<0.05)$. In the type II nutrition medium, there was a discrepancy found between I, II, III and IV groups $(p<0.05)$. The lipid levels of $S$. platensis which was produced in the types I and II groups are found to be higher than that found in the types III and IV groups of both nutrition media (Figure 4). It can be concluded that the addition of sodium bicarbonate into the III and IV groups could be responsible. Vonshak et al. (1982) reported that this took place due to the partial $\mathrm{CO}_{2}$ pressure of biomass values being high at high temperatures and the acceleration of photosynthesis. The results that the researchers reported support our findings. Danesi et al. (2002) reported that the lipid contents in the biomass of $S$. platensis are not under the influence of nitrogen source that was used. In our study, there was no discrepancy found in the lipid rates of the various concentrations of urea and sodium bicarbonate in both nutrition media. Our results are consistent with the results that Danesi et al. (2002) reported. Ungsethaphand (2009) reported that the highest protein content is obtained from the media in which urea and urea + sodium bicarbonate is added into the chicken manure. The increase in the protein content takes place due to the nitrogen levels increase in the environment (Ungsethaphand, 2009). In our study, the highest protein ratio is obtained from the groups in which urea and urea + sodium bicarbonate were added into the chicken manure. Our findings are consisted with the results that were obtained from the studies conducted by Ungsethaphand (2009).

In the study conducted by Koru and Cirik (2003), the protein ratio of S. platensis was reported to be $57.5 \%$ and the lipid ratio as $8 \%$. In our study, the ratios of lipid and protein are found respectively, between 2.59 to 4.96 , 35.51 to $44.98 \%$. Based on the results that the researchers 


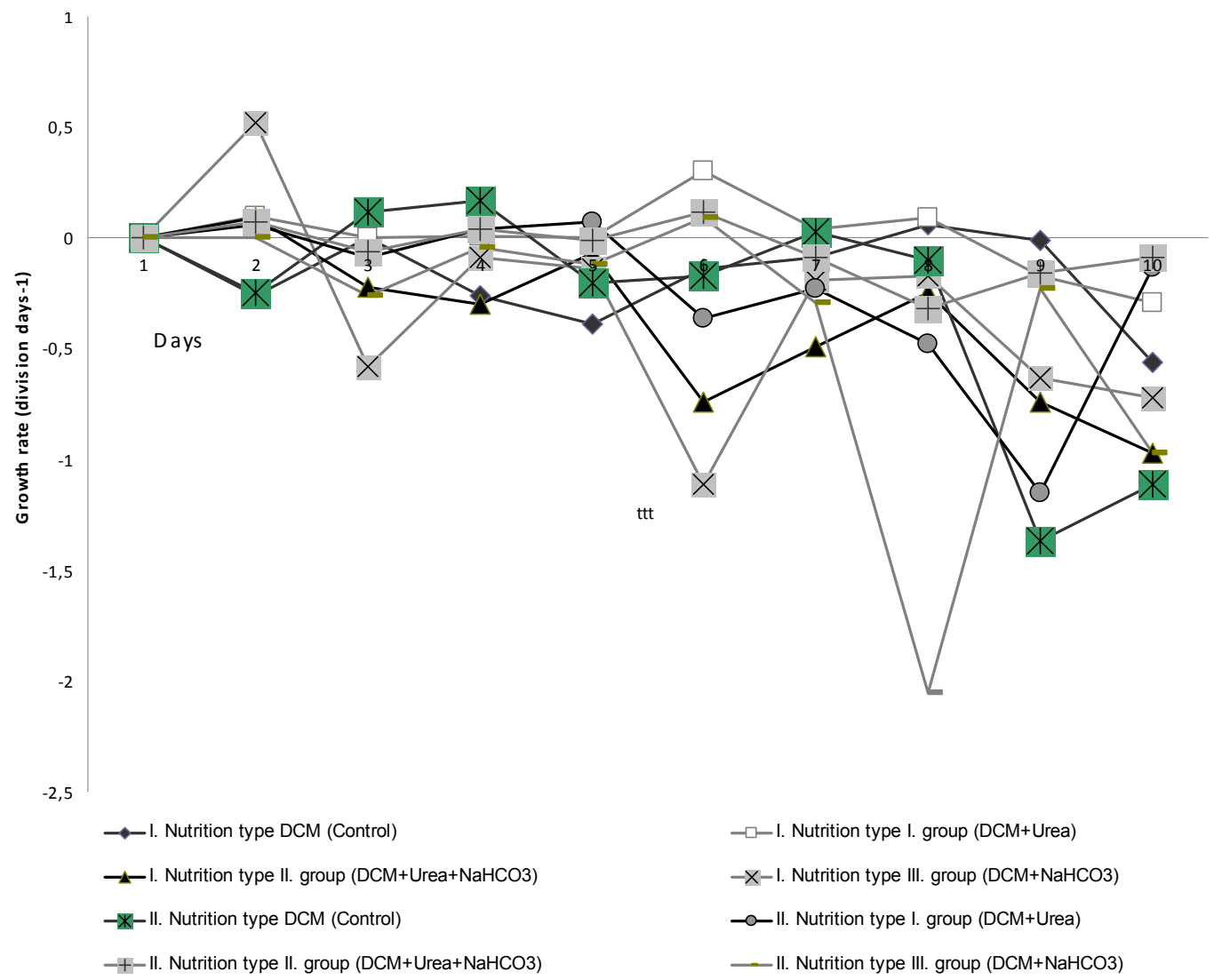

Figure 3. Daily growth rates (division day ${ }^{-1}$ ) of S. platensis were cultivated in I and II type of nutrition with DCM.

目 I. Nutrition type Lipid ratio

IIII I. Nutrition type Protein ratio
II. Nutrition type Lipid ratio

a II. Nutrition type Protein ratio

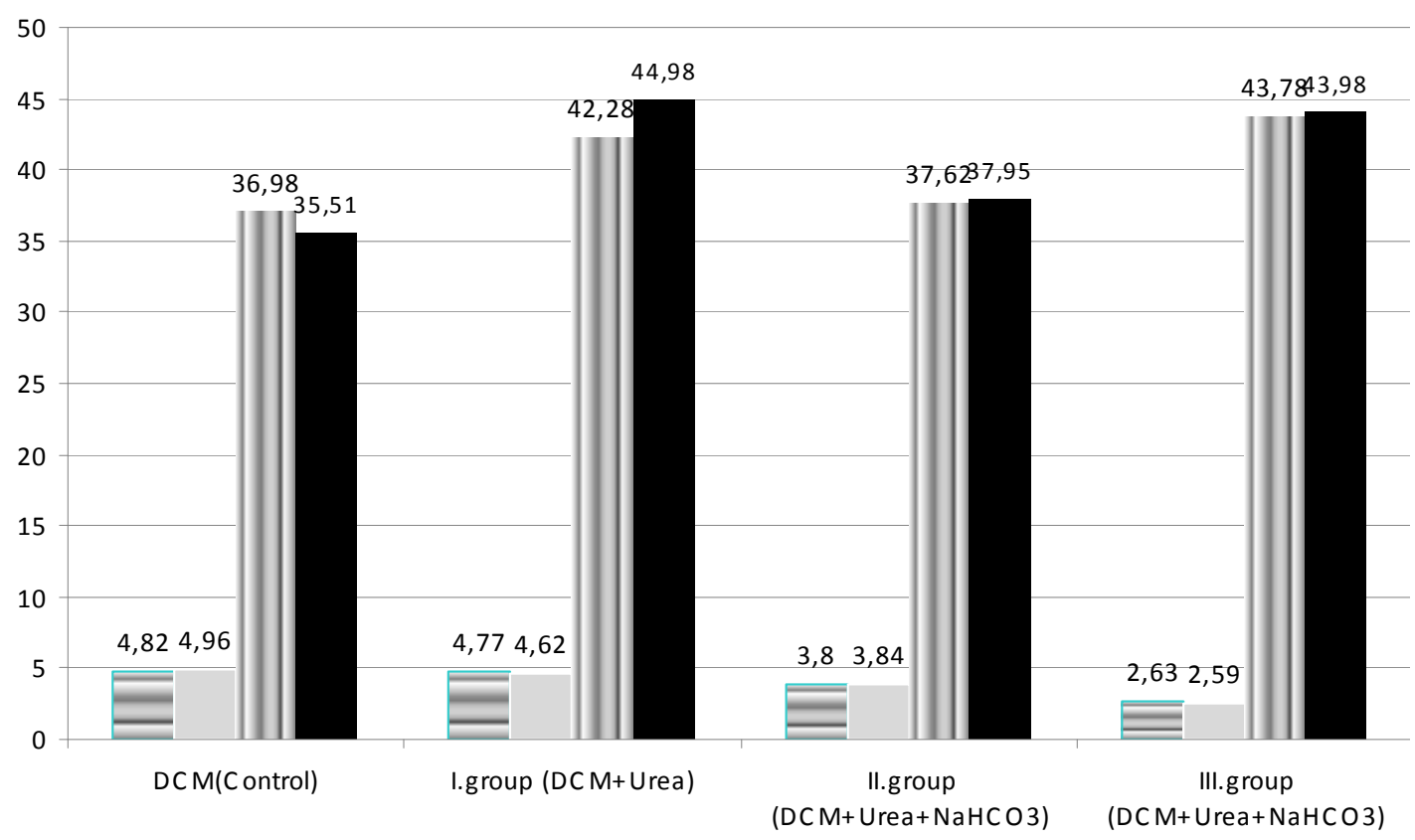

Figure 4. Lipid and protein ratio of S. platensis were cultivated in I and II type of nutrition with DCM. 
reported, it was concluded that the low protein and lipid ratios that was obtained in our study is due to the differences in the nutrition media.

It was determined that usage of $1.0 \mathrm{mg} / \mathrm{L}$ urea $+20 \mathrm{mg} / \mathrm{L}$ $\mathrm{NaCO}_{3}$ added $200 \mathrm{mg} / 10 \mathrm{~L}$ of DCM (in type II nutrition) gave the best cellular increase and usage of $2.0 \mathrm{mg} / \mathrm{L}$ urea added $200 \mathrm{mg} / 10 \mathrm{~L}$ of DCM (in type I nutrition) gave the best cellular increase and the best protein ratio. In this case, we can say that suppressive effect of $\mathrm{NaCO}_{3}$ decreased when the amount of urea and $\mathrm{NaCO}_{3}$ had been halved.

\section{Conflict of interests}

The author(s) have not declared any conflict of interests.

\section{REFERENCES}

AOAC (1984). Official Methods of Analysis $14^{\text {th }}$. Ed. Association of Official Analytical chemists, Washington, DC, USA.

Babadzhanov AS, Abdusamatova N, Yusupova FM, Faizullaeva N, Mezhlumyan LG, Malikova MK (2004). Chemical composition of Spirulina platensis cultivated in Uzbekistan. Chem. Nat. Compounds. 40(3): 276-279.

Binaghi L, Del Borghi A, Lodi A, Converti A, Del Borghi M (2003). Batch and fed-batch uptake of carbon dioxide by Spirulina platensis. Proc. Biochem. 38:1341-1346.

Blig EG, Dyer WJ (1959). A rapid method of total lipid extraction and purification. Can. J. Biochem. Physiol. 37: 911-917.

Blunden G, Whapham C, Jenkins T (1992). Seaweed Extracts in Agriculture and Horticulture: Their Origins, Uses and Modes of Action. School of Pharmacy and Biomedical Science and School of Biological Sciences, University of Portsmouth, King Henry John Street, Portsmouth, Hampshire P01 U.K. p. 202.

Boussiba S (1989). Ammonia uptake in the alkalophilic cyanobacteria Spirulina platensis. Plant Cell Physiol. 30:303-308.

Challem JJ (1981). Spirulina:What It Is. The Health Benefits It Can Give You. Keats Publishing Inc., New Canaan, CT.

Cheunbarn S (2010). Yuwadee Peerapornpisal, "Cultivation of Spirulina platensis using Anaerobically Swine Wastewater Treatment Effluent". Faculty of Science, Maejo University, Chiang Mai 50290, Thailand.

Costa JAV, Colla LM, Filho PFD (2004). Improving Spirulina platensis biomass yield using a fed-batch process. Bioresour. Technol. 92: 237-241.

Danesi EDG, Rangel-Yagui CO, Carvalho JCM, Sato S (2004). Effect of reducing the light intensity on the growth and production of chlorophyll by Spirulina platensis. Biomass and Bioenergy. 26: 329335.

Davis AR (1977). Principles of Oceanography. University of South Florida Aquafarms, Inc., Florida. p. 126.

Geitler L (1932). Cyanophyceae. In: Rabenhorst L. (ed). Rabenhorst's Kryptogamen-Flora von Deutchland. O" sterreich und der Schweiz, Akademische Verlagsgesellschaft, Leipzig. 14: 1-1196.

Gökpınar Ş (1991). Akuakültürde önemli beş deniz flagellatlatının inorganik $\mathrm{N}$ alınımları üzerine sıcaklık değişimlerinin etkisi. The Institute of Marine Sciences and Technolohgy of Dokuz Eylül University. PhD Thesis, İzmir, p. 88.

Guillard RRL (1973). Division rates. In, Stein (ed), Handbook of Phycological Methods,V. 1, Cambridge University Press, Cambridge. pp. 289-312.

Kendirli K (2010). Spirulina Kültürlerinde Besin Elementlerinin Farklı Oranlarda Kullanımının Kuru Madde, Protein ve Klorofil-a Düzeyine Etkisi, Çukurova University Institute of Natural and Applied Sciences, MSc Thesis. p. 5.
Koru E, Cirik S (2003). Spirulina platensis (Cyanophyceae) Mikroalg'inin Büyümesine ve Bazı Biyokimyasal Özelliklerine Sıcaklığın Etkisi. Ege University. J. Fish. Aquat. Sci. 20(3-4): 419-422.

Mubeen, U., Hussain, W., Ikram-ul-Haq and Kauser Abdullah Malik 2011. Study of Native Algal Species for Growth Potential and Lipid Yield. Current Res. J. Biol. Sci. 3(3): 240-245, ISSN: 2041-0778.

Ratana C, Chirasuwan N, Siangdung W (2009). Kalyanee Paithoonrangsarid and Boosya Bunnag, "Cultivation of Spirulina platensis Using Pig Wastewater in a Semi-Continuous Process". J. Microbiol. Biotechnol. 20(3): 609-614.

Schlosser UG (1982). Sammlung von Algenkulturen. Berichte der Deutschen Botanischen Gesellschaft. 95: 181-276.

Semina HJ (1978). Treatment of an Aliquot Sample. (Editor; In Sournia, A., Phytoplankton Manual,), UNESCO, Paris. p. 181.

Stanca D, Popovici E (1996). Urea as nitrogen source in modified Zarrouk medium. Review Roum. Biology 41: 25-31.

Ungsethaphand T, Peerapornpisal Y, Whangchai N (2009). Production of Spirulina platensis using dry chicken manure supplemented with urea and sodium bicarbonate. Maejo Int. J. Sci.Technol. 3: 379-387.

Ungsethaphand T, Peerapornpisal Y, Whangchai N, Sardsud U (2007). Productivity and chemical composition of Spirulina platensis using dry chicken manure as nitrogen sources. Proceedings of the 19th Annual Meeting of the Thai Society for Biotechnology, Bangkok, Thailand, pp. 43-48.

Vonshak A, Abeliovich A, Boussiba S, Arad S, Richmond A (1982). Production of Spirulina biomass: effects of environmental factors and population density. Biomass 2: 175-185.

Xu N, Zhang X, Fan X, Han L, Zeng C (2001). Effect of nitrogen source and concentration on growth rate and fatty acid composition of Ellipsoidion sp. (Eustigmatophyta). J. Appl. Phycol. 13: 463-469. 